\title{
A clinical study of uropathogens causing urinary tract infection in children and adolescents in a tertiary care hospital
}

\author{
R. Abisha Rezia ${ }^{1}$, R. Vijendra ${ }^{1 *}$, Anjana Gopi²
}

\begin{abstract}
${ }^{1}$ Department of Pharmacology, Kempegowda Institute of Medical Sciences, Bangalore, Karnataka, India ${ }^{2}$ Department of Microbiology, Kempegowda Institute of Medical Sciences, Bangalore, Karnataka, India
\end{abstract}

Received: 29 July 2020

Accepted: 01 September 2020

\author{
*Correspondence: \\ Dr. R. Vijendra, \\ Email: vijendra_ramaiah@yahoo.co.in
}

Copyright: () the author(s), publisher and licensee Medip Academy. This is an open-access article distributed under the terms of the Creative Commons Attribution Non-Commercial License, which permits unrestricted non-commercial use, distribution, and reproduction in any medium, provided the original work is properly cited.

\begin{abstract}
Background: Urinary Tract Infection (UTI) is one of the common infections in children. Incidence varies with age, race and gender. UTIs have become difficult to treat due to development of resistance among uropathogens. Regional data regarding the common uropathogens and their antimicrobial susceptibility pattern is required to guide the clinicians to start empirical therapy while treating UTIs.

Aims: This study is aimed to study the profile of uropathogens causing UTI in children and adolescents, assess their antimicrobial susceptibility, the clinical course and outcome.

Methods: All subjects with suspected UTI whose urine samples grew a positive culture of uropathogens were included in this prospective observational study. The study was done in the Department of Microbiology from July 2019 to December 2019. The urine samples were processed by standard methods (using 5\% sheep blood agar and MacConkey agar) and antimicrobial susceptibility was performed using the Kirby-Bauer disk diffusion method. The details of the pathogens grown, and their antimicrobial sensitivity and resistance patterns were recorded, and the subjects were followed up during their course in the hospital.

Results: A total of 109 urine samples from paediatric and adolescent subjects showed positive cultures (97.32\%). UTI was common among toddlers (46.7\%). E. coli contributed to $40.3 \%$ of the cases, followed by Enterococcus and Klebsiella pneumonaie. E. coli was resistant to amoxicillin + clavulanic acid, cephalosporins and ciprofloxacin. The organisms were sensitive to meropenem, amikacin and piperacillin + tazobactam.

Conclusion: Incidence of UTI and the uropathogens causing UTI varies with age. Different uropathogens and their resistance to commonly used antimicrobials is a concern for future treatment options in UTI.
\end{abstract}

Keywords: Urinary tract infection, Children, Adolescents, Antimicrobial drug resistance

\section{INTRODUCTION}

Urinary tract infection (UTI) is infection involving any part of the urinary tract- kidneys, ureters, bladder and urethra. UTI is a common problem in children. ${ }^{1}$ The incidence varies with age, race and gender. ${ }^{2,3}$ UTI occurs in $1 \%$ boys and $3-5 \%$ girls. ${ }^{4}$ It affects male children more than females in the first year of life and females after 1 year of age. ${ }^{5}$ Three to five percent of febrile children are found to have UTI. ${ }^{6}$ In infants and children, the symptoms of UTI may be minimal and non-specific. ${ }^{7}$ Febrile children not suspected of having UTI are as likely to have UTI as those who are suspected of having UTI. ${ }^{8}$ Hence diagnosis of UTI cannot be made on symptomatology alone. Urine examination and culture should be done in children even with minimal suspicion of UTI. ${ }^{9,10}$ Complications of UTI include sepsis and renal scaring, which is the most common cause of hypertension in later childhood and renal failure in adulthood. ${ }^{2,7}$ 
Diagnosis should be made as early as possible to prevent these complications. At least $80 \%$ of UTI in children is caused by Escherichia coli followed by other uropathogens like Proteus, Enterococcus, Pseudomonas, Klebsiella species, Citrobacter and Staphylococcus aureus. Selection of antimicrobials is based on antimicrobial susceptibility patterns which vary over short periods. ${ }^{11}$ Increasing antimicrobial resistance among uropathogens, to commonly prescribed drugs has become a global reality. ${ }^{12}$ Use of antimicrobials by medical practitioners is rampant and has resulted in increase in resistance. Hence isolation of organisms causing UTI and their antimicrobial susceptibility pattern is essential for appropriate management. The objective of this study was to study the profile of uropathogens causing UTI in children and adolescents in a tertiary care hospital in South India and also assess their antimicrobial susceptibility pattern, clinical course and outcome.

\section{METHODS}

This study was a prospective, observational clinical study conducted in the Department of Microbiology at Kempegowda Institute of Medical Sciences and Research Centre, Bangalore. The study was conducted between July 2019 and December 2019 after approval by the Institutional Ethics Committee (IEC). The study was registered with Clinical Trial Registry- India (CTRI). All the subjects with suspected UTI $(n=1445)$, whose urine samples were processed during the study period were examined for eligibility. (Non-probability sampling: convenience sampling). Data regarding the age, gender, reason for hospitalization, use of empirical antimicrobials, source of the urine samples, the organisms cultured, and their sensitivity and resistance patterns were noted. The subjects were followed up during their course in the hospital.

Inclusion criteria included children and adolescents (11 to 19 years) whose urine sample when processed showed significant growth of one or more organisms $(n=109)$.

Subjects whose urine sample was contaminated, subjects whose urine sample showed no growth and subjects whose urine sample showed insignificant bacteriuria were excluded from the study.

Samples were obtained by supra-pubic aspiration from neonates in the Neonatal Intensive Care Units (NICUs). Fresh midstream clean catch urine samples were collected aseptically in sterile containers, from the children and adolescents reporting to the various out-patient departments and from the in-patients of different wards. Each sample was plated onto 5\% sheep blood agar and MacConkey agar plates using a calibrated loop, delivering $0.01 \mathrm{ml}$ of the sample. This was incubated at $37^{\circ} \mathrm{C}$ overnight and the observation was made the next day. All plates showing significant growth $(>105 \mathrm{CFU} / \mathrm{ml})$ as per the Kass count were were subjected to antimicrobial sensitivity testing. For Staphylococcus aureus, even <10 colonies $(10 \mathrm{CFU} / \mathrm{ml})$ were further processed as this was considered significant. After biochemical identification of the organisms, anti-microbial sensitivity testing was done for the isolates using Kirby Bauer disc diffusion methods on Mueller Hinton agar and results were interpreted as per the National Committee for Clinical Laboratory Standards (NCCLS) guidelines.

The data collected were analysed and the results were depicted in the form of percentages, graphs or bar charts.

\section{RESULTS}

Urine samples of 109 subjects showed positive urine culture. All the positive cultures were due to bacterial uropathogens and no candida species were reported.

Table 1 shows the demographic profile of the cases in the study. Table 2 shows the case distribution of the study subjects.

Table 1: Demographic profile of the cases in the study.

\begin{tabular}{|lll|}
\hline Demographic profile & $\mathbf{N}(\%)$ \\
\hline Age (years)*\# & $\begin{array}{l}\text { Toddlers } \\
\text { (1 to 3 years) }\end{array}$ & $51(46.7)$ \\
\hline $\begin{array}{l}\text { Pre-school and } \\
\text { school age } \\
\text { (4 to 10 years) }\end{array}$ & $\begin{array}{l}\text { Adolescents } \\
\text { (11 to 19 years) }\end{array}$ & $19(17.4)$ \\
\hline & $\begin{array}{l}\text { Infants } \\
\text { (1 month to 1 year) }\end{array}$ & $11(10)$ \\
\hline $\begin{array}{l}\text { Neonates } \\
\text { (less than 28 days) }\end{array}$ & $2(1.8)$ \\
\hline Gender & Male & $51(46.7)$ \\
\hline Female & $58(53.2)$ \\
\hline
\end{tabular}

*Age of the subjects ranged from 4 days to 19 years; \#Mean age $1867.5 \pm 2071.8$ days

Table 2: Case distribution of the study subjects.

\begin{tabular}{|c|c|c|}
\hline Variables & & $\mathbf{N}(\%)$ \\
\hline \multirow{3}{*}{$\begin{array}{l}\text { Distribution } \\
\text { of the cases }\end{array}$} & Culture positive & $106(94.6 \%)$ \\
\hline & $\begin{array}{l}\text { Multi-drug resistant } \\
\text { (MDR) cases }\end{array}$ & $2(1.8 \%)$ \\
\hline & $\begin{array}{l}\text { Mixed infections } \\
\text { (Culture of more } \\
\text { than one organism) }\end{array}$ & $1(0.9 \%)$ \\
\hline \multirow{3}{*}{$\begin{array}{l}\text { Source of the } \\
\text { cases }\end{array}$} & In-patients & $89(81.7 \%)$ \\
\hline & Out-patients & $15(13.7 \%)$ \\
\hline & ICUs & $5(4.6 \%)$ \\
\hline \multirow{2}{*}{$\begin{array}{l}\text { Source of the } \\
\text { urine } \\
\text { specimen }\end{array}$} & $\begin{array}{l}\text { Fresh midstream } \\
\text { urine }\end{array}$ & $96(88 \%)$ \\
\hline & $\begin{array}{l}\text { Suprapubic } \\
\text { aspiration }\end{array}$ & $13(12 \%)$ \\
\hline
\end{tabular}

The reasons for hospitalization in the paediatric Intensive care unit (ICU) was acute gastroenteritis $(n=1)$ and in the 
NICU was fever with gastroenteritis $(n=3)$ and sepsis $(n=1)$.

Most in-patients were hospitalized for fever with suspected UTI $(n=65)$. The other reasons were for acute gastroenteritis $(n=7)$, viral fever $(n=8)$, dengue fever $(n=4)$ and enteric fever $(n=2)$. Urine culture in the out-patients was done for fever with suspected UTI $(n=15)$.

Table 3: Profile of culture positive uropathogens $(n=109)$.

\begin{tabular}{|c|c|}
\hline Culture positive organisms & $\mathbf{N}(\%)$ \\
\hline Escherichia coli & $44(40.3)$ \\
\hline Enterococcus spp ${ }^{\#}$ & $23(21.1)$ \\
\hline Klebsiella spp* & $19(17.43)$ \\
\hline Proteus spp & $9(8.25)$ \\
\hline Acinetobacter spp \# $^{\#}$ & $5(4.6)$ \\
\hline Psedumonas aeruginosa & $3(2.8)$ \\
\hline Staphylococcus aureus & $2(1.8)$ \\
\hline Citrobacter spp p $^{\#}$ & $2(1.8)$ \\
\hline Enterobacter spp \# $^{\#}$ & $2(1.8)$ \\
\hline
\end{tabular}

*Klebsiella pneumoniae: $\mathrm{n}=11$, Klebsiella oxytoca: $\mathrm{n}=8$ \#Speciation was not conducted

Table 4: Culture positive uropathogens and resistance pattern.

\begin{tabular}{|c|c|}
\hline Organisms & $\begin{array}{l}\text { Resistance shown to } \\
\text { antimicrobial agents }\end{array}$ \\
\hline \multirow{2}{*}{$\begin{array}{l}\text { Escherichia coli } \\
(n=44)\end{array}$} & $\beta$-lactam antibiotics $*(n=35)$ \\
\hline & Fluoroquinolones\# $(\mathrm{n}=9)$ \\
\hline \multirow{3}{*}{$\begin{array}{l}\text { Enterococcus spp } \\
(\mathrm{n}=23)\end{array}$} & $\beta$-lactam antibiotics* $(n=4)$ \\
\hline & Lincosamide $\uparrow(n=7)$ \\
\hline & Aminoglycoside $\div(\mathrm{n}=12)$ \\
\hline \multirow{3}{*}{$\begin{array}{l}\text { Klebsiella spp } \\
(\mathrm{n}=19)\end{array}$} & $\beta$-lactam antibiotics $*(n=10)$ \\
\hline & Fluoroquinolones\# $(\mathrm{n}=5)$ \\
\hline & Urinary antiseptics $\S(n=4)$ \\
\hline \multirow{2}{*}{ Proteus spp $(\mathrm{n}=9)$} & $\beta$-lactam antibiotics* $(n=6)$ \\
\hline & Urinary antiseptics $(n=3)$ \\
\hline \multirow{2}{*}{$\begin{array}{l}\text { Acinetobacter spp } \\
(\mathbf{n}=5)\end{array}$} & $\beta$-lactam antibiotics* $(n=4)$ \\
\hline & Urinary antiseptics $\S(n=1)$ \\
\hline \multirow{2}{*}{$\begin{array}{l}\text { Psedumonas } \\
\text { aeruginosa }(\mathrm{n}=3)\end{array}$} & $\beta$-lactam antibiotics* $(n=2)$ \\
\hline & Aminoglycoside $+(\mathrm{n}=1)$ \\
\hline \multirow{2}{*}{$\begin{array}{l}\text { Staphylococcus } \\
\text { aureus }(\mathrm{n}=2)\end{array}$} & $\beta$-lactam antibiotics* $(n=1)$ \\
\hline & Macrolides I[ $(\mathrm{n}=1)$ \\
\hline \multirow{2}{*}{$\begin{array}{l}\text { Citrobacter spp } \\
(\mathrm{n}=2)\end{array}$} & $\beta$-lactam antibiotics* $(n=1)$ \\
\hline & Urinary antiseptics $§(n=1)$ \\
\hline \multirow{2}{*}{$\begin{array}{l}\text { Enterobacter spp } \\
(\mathrm{n}=2)\end{array}$} & $\beta$-lactam antibiotics* $(n=1)$ \\
\hline & Urinary antiseptics $\S(n=1)$ \\
\hline
\end{tabular}

Table 3 denotes the profile of culture positive uropathogens.
No Candida species were reported in children.

There were two cases of Multi-drug resistant (MDR) uropathogens- one each of Klebsiella pneumoniae $(n=1$; $0.9 \%)$ and Klebsiella oxytoca $(n=1 ; 0.9 \%)$. Both these multi drug resistant (MDR) cases were treated with ciprofloxacin.

Mixed infection was seen with Escherichia coli and enterococcus spp.

Table 5: Culture positive isolates and sensitivity pattern.

\begin{tabular}{|c|c|}
\hline Organisms & Sensitive AMAs \\
\hline \multirow{3}{*}{$\begin{array}{l}\text { Escherichia coli } \\
(n=44)\end{array}$} & Piperacillin + tazobactam $(n=30)$ \\
\hline & Meropenem $(n=9)$ \\
\hline & Gentamicin $(n=5)$ \\
\hline \multirow{3}{*}{$\begin{array}{l}\text { Enterococcus spp } \\
(\mathrm{n}=23)\end{array}$} & $\begin{array}{l}\text { Amoxicillin + clavulanic acid } \\
(n=10)\end{array}$ \\
\hline & Levofloxacin $(n=7)$ \\
\hline & Vancomycin $(n=6)$ \\
\hline \multirow{3}{*}{ Klebsiella spp $(\mathrm{n}=19)$} & Amikacin $(n=5)$ \\
\hline & Tobramycin $(n=4)$ \\
\hline & Meropenem $(n=10)$ \\
\hline \multirow{4}{*}{ Proteus spp $(\mathrm{n}=9)$} & Gentamicin $(n=2)$ \\
\hline & Amikacin, Netilmicin $(n=2)$ \\
\hline & Ciprofloxacin $(n=2)$ \\
\hline & Meropenem $(n=3)$ \\
\hline \multirow{3}{*}{$\begin{array}{l}\text { Acinetobacter spp } \\
(\mathrm{n}=5)\end{array}$} & Amikacin, tobramycin $(n=1)$ \\
\hline & Meropenem $(n=1)$ \\
\hline & Piperacillin + tazobactam $(n=3)$ \\
\hline \multirow{3}{*}{$\begin{array}{l}\text { Psedumonas } \\
\text { aeruginosa }(\mathrm{n}=3)\end{array}$} & Amikacin, netilmicin $(n=1)$ \\
\hline & Tobramycin $(n=1)$ \\
\hline & Meropenem $(n=1)$ \\
\hline \multirow{2}{*}{$\begin{array}{l}\text { Staphylococcus } \\
\text { aureus }(\mathrm{n}=2)\end{array}$} & Gentamicin $(n=1)$ \\
\hline & Ciprofloxacin $(n=1)$ \\
\hline \multirow{2}{*}{$\begin{array}{l}\text { Citrobacter spp } \\
(\mathrm{n}=2)\end{array}$} & Meropenem $(n=1)$ \\
\hline & Netilmicin $(\mathrm{n}=1)$ \\
\hline \multirow{2}{*}{$\begin{array}{l}\text { Enterobacter spp } \\
(\mathrm{n}=2)\end{array}$} & Meropenem $(n=1)$ \\
\hline & Tobramycin $(n=1)$ \\
\hline
\end{tabular}

Table 6 depicts the empirical antimicrobials used. Empirical antimicrobials were used in $9.2 \%(n=10)$ and all the empirical antimicrobials were administered through the intravenous (IV) route.

\section{Clinical outcome}

The subjects responded to treatment with piperacillin + tazobactam $(n=33)$, meropenem $(n=26)$, gentamicin $(n=8)$, amoxicillin + clavulanic acid $(n=10)$, levofloxacin $(n=7)$, vancomycin $(n=6)$, amikacin $(n=5)$, tobramycin $(n=7)$, netilmicin $(n=4)$ and ciprofloxacin $(n=3)$. Repeat urine culture was negative in all the subjects and they were discharged after they fully recovered from the UTI. 
Table 6: Empirical antimicrobials used.

\begin{tabular}{|lll|}
\hline \multirow{5}{*}{ Organism } & Empirical antimicrobials $(\mathrm{n}=\mathbf{1 0})$ & Indication for use of the AMA \\
\cline { 2 - 3 } Escherichia coli $(\mathbf{n}=\mathbf{5})$ & Ceftriaxone $(\mathrm{n}=1)$ & Febrile convulsion \\
\cline { 2 - 3 } & Amikacin $(\mathrm{n}=1)$ & Fever with suspected UTI \\
\cline { 2 - 3 } & Ciprofloxacin $(\mathrm{n}=1)$ & Enteric fever \\
\cline { 2 - 3 } & Ofloxacin $(\mathrm{n}=1)$ & Acute gastroenteritis \\
\cline { 2 - 3 } & Amoxicillin + clavulanic acid* $(\mathrm{n}=1)$ & Fever with suspected UTI \\
\hline \multirow{2}{*}{ Klebsiella oxytoca $(\mathbf{n}=\mathbf{2})$} & Ceftriaxone $(\mathrm{n}=1)$ & Viral fever \\
\cline { 2 - 3 } & Ofloxacin $(\mathrm{n}=1)$ & Acute gastroenteritis \\
\hline Klebsiella pneumoniae $(\mathbf{n}=\mathbf{1})$ & Ceftriaxone $(\mathrm{n}=1)$ & Viral fever \\
\hline Enterococcus $(\mathbf{n}=\mathbf{1})$ & Ceftriaxone $(\mathrm{n}=1)$ & Viral fever \\
\hline Proteus vulgaris $(\mathbf{n}=\mathbf{1})$ & Ceftriaxone $(\mathrm{n}=1)$ & Viral fever \\
\hline
\end{tabular}

*Fixed dose combinations (FDCs).

Table 7: World Health Organisation (WHO) lists the following organisms as priority pathogens. ${ }^{13}$

\begin{tabular}{|c|c|}
\hline Priority & Pathogens \\
\hline \multirow{3}{*}{$\begin{array}{l}\text { Priority 1: } \\
\text { Critical }\end{array}$} & $\begin{array}{l}\text { Acinetobacter baumannii, } \\
\text { carbapenam-resistant }\end{array}$ \\
\hline & $\begin{array}{l}\text { Pseudomonas aeruginosa, } \\
\text { carbapenam-resistant }\end{array}$ \\
\hline & $\begin{array}{l}\text { Enterobacteriaceae, carbapenam- } \\
\text { resistant, ESBL-producing }\end{array}$ \\
\hline \multirow{6}{*}{$\begin{array}{l}\text { Priority 2: } \\
\text { High }\end{array}$} & $\begin{array}{l}\text { Enterococcus faecium, vancomycin- } \\
\text { resistant }\end{array}$ \\
\hline & $\begin{array}{l}\text { Staphylococcus aureus, methicillin- } \\
\text { resistant, vancomycin-intermediate } \\
\text { and resistant }\end{array}$ \\
\hline & $\begin{array}{l}\text { Helicobacter pylori, clarithromycin- } \\
\text { resistant }\end{array}$ \\
\hline & $\begin{array}{l}\text { Campylobacter spp, fluoroquinolone } \\
\text { resistant }\end{array}$ \\
\hline & $\begin{array}{l}\text { Salmonellae, fluoroquinolone } \\
\text { resistant }\end{array}$ \\
\hline & $\begin{array}{l}\text { Neisseria gonorrhoeae, } \\
\text { cephalosporin-resistant, } \\
\text { fluoroquinolone-resistant }\end{array}$ \\
\hline \multirow{3}{*}{$\begin{array}{l}\text { Priority 3: } \\
\text { Medium }\end{array}$} & $\begin{array}{l}\text { Streptococcus pneumonia, penicillin- } \\
\text { non-susceptible }\end{array}$ \\
\hline & $\begin{array}{l}\text { Haemophilus influenza, ampicillin- } \\
\text { resistant }\end{array}$ \\
\hline & $\begin{array}{l}\text { Shigella spp, fluoroquinolone- } \\
\text { resistant }\end{array}$ \\
\hline
\end{tabular}

Table 7 gives information about the WHO priority pathogens. None of these organisms were encountered in our study.

\section{DISCUSSION}

The changing antimicrobial susceptibility patterns of the organisms is common in developing countries like India, where antimicrobials are prescribed irrationally and they are purchased from the chemists over-the-counter without a prescription. ${ }^{14}$ Thus paediatricians should be aware of the rising trends of resistance of uropathogens to the commonly prescribed antibiotics as well as the profile of resistance within their community. ${ }^{15}$ Periodic evaluation of the susceptibility pattern is essential for rational and appropriate use of antimicrobials. ${ }^{11}$

UTI incidence varies with age and gender. It occurs in one percent of boys and 3-5\% of girls. However, in contrast to this, the present study showed a marginally higher positive rate among male children as compared with female children. Majority of the culture positive cases were in the toddler age group (1-3 years). This was in agreement with a study done in Iran. ${ }^{16}$ The probable reason could be that children in this age group are not properly toilet trained and hence likelihood of ascending infection with fecal flora is more common. ${ }^{4,7}$

Escherichia coli was the most common uropathogen isolated and constituted $40.3 \%(n=44)$ of all the positive samples. This is less than the finding observed by Rimal et al E.coli constituted $59.4 \%$ of the nosocomial UTI in hospitalized patients as reported by Das et al. ${ }^{17}$ Another study in children reported $96.4 \%$ urinary isolates of E.coli. ${ }^{18}$ With regard to antibiotic sensitivity pattern of the isolates, E.coli was found to be most sensitive to amikacin, piperacillin and tazobactam, meropenem and netilmicin. Rajbhandari et al earlier reported nitrofurantoin as the most sensitive antibiotic followed by gentamicin, norfloxacin and ciprofloxacin. ${ }^{19}$

Proteus spp which includes Proteus mirabilis $(1.8 \% ; \mathrm{n}=2)$ and Proteus vulgaris $(6.4 \% ; \mathrm{n}=7)$ was identified as a causative agent for UTI only in a small number of cases in this study. This was similar to a study by Shrestha et al. ${ }^{20}$ Proteus spp was found sensitive to ciprofloxacin, amikacin, gentamicin, meropenem and piperacillin + tazobactam. It was resistant to nalidixic acid and nitrofurantoin. In a study by Rajbhandari et al Proteus spp were reported to be sensitive to nalidixic acid. ${ }^{19}$

Klebsiella spp constituted the third most common uropathogen for UTI. It accounted for $17.43 \%(n=19)$ of the cases. On the contrary, Moderres et al found Klebsiella 
spp in $10.5 \%$ of the children. ${ }^{16}$ It was sensitive to amikacin, gentamicin, tobramycin and meropenem and resistant to amoxicillin and clavulanic acid, cefepime, cefuroxime, ciprofloxacin, nitrofurantoin and nalidixic acid. This was contrary to the reports in another study which suggested that quinolone group- norfloxacin, nalidixic acid and nitrofurantoin was sensitive and most effective. ${ }^{19}$

The gram positive uropathogens isolated in our study were Enterococcus $21.1 \%(\mathrm{n}=23)$, Staphylococcus aureus and Methicillin Resistant Staphylococcus aureus (MRSA) $0.9 \%(n=1)$ each. This is in contrast to another study report where Staphylococcus aureus was $2.7 \%$ to $12.2 \% .^{19}$

\section{CONCLUSION}

The incidence of UTI varies with age. Different uropathogens and their resistance to commonly used antimicrobials is a concern for future treatment options in UTI. The findings in this study suggest the need of periodic monitoring of antimicrobial susceptibility pattern of the bacterial isolates. This will help the clinicians in selecting empirical therapy for treatment of UTI in children and also in providing cost effective treatment in developing countries like India and elsewhere.

\section{ACKNOWLEDGEMENTS}

Thankful to the Department of Microbiology for providing the necessary data.

\section{Funding: No funding sources} Conflict of interest: None declared

Ethical approval: The study was approved by the Institutional Ethics Committee

\section{REFERENCES}

1. Gulati S, Kher V. Urinary tract infection. Indian Pediatr. 1996;33:212-7.

2. Bickerton MW, Ducket JW. Urinary tract infection in pediatric patients. American Urological Association, Houston, Texas. 1985.

3. Shaw KN, Gorelick M, Mcgowan KL, Yakscore NM, Schwartz JS. Prevalence of urinary tract infection in febrile young children in the emergency department. Pediatr. 1998;102:16-21.

4. Elder JS. Urinary tract infections. In: Kliegman RM, Behrman RE, Jenson HB, Stanton BE, editors. Nelson Textbook of Pediatrics. Philadelphia: Saunders. 2007;2223-8.

5. Watson AR. Disorders of the urinary syastem. In: Campbell AG, McIntosh N, editors. Forfar and Arneil's Textbook of Pediatrics. Churchill Livinstone. 1998;949. 56.

6. Bachur R, Harper MB. Reliability of the urinanalysis for predicting urinary tract infections in young febrile children. Arch Pediatr Adoles Med. 2001;155:60-5.
7. Chon CH, Lai FC, Shorthffe LM. Pediatric urinary tract infections. Pediatr Clin North Amer. 2001;48:1447-59.

8. Oak SN, Agarwal P. Urinary tract infection in children and role of surgery. Asian J Pediatr Practice. 2001;4:436.

9. Srivaths PR, Rath B, Krishna PS, Talukdar B. Usefulness of screening febrile infants for urinary tract infection. Indian Pediatr. 1996;33:218-20.

10. Chantler C, Berman LH, Jones FC, Gruneberg RN, Haycock GB. Guidelines for the management of acute urinary tract infection in childhood. J Roy Col Physician London. 1991;25:36-41.

11. Jones RN, Thornsberry C. Cefotaxime: a review of in vitro antimicrobial properties and spectrum of activity. Rev Infect Dis. 1982;4:5300-15.

12. Manges AR, Johnson JR, Foxman B, O'Bryan TT, Fullerton KE, Riley LW. Widespread distribution of urinary tract infections caused by a multidrug-resistant Escherichia coli clonal group. New Engl J Med. 2001;345:1007-13.

13. "WHO publishes list of bacteria for which new antibiotics are urgently needed." WHO, 27 February 2017, https://www.who.int/news-room/detail/27-022017-who-publishes-list-of-bacteria-for-which-newantibiotics-are-urgently-needed. Last accessed on 29 June 2020.

14. Palikhe N. Prescribing pattern of antibiotics in pediatric hospital of Kathmandu Valley. Kathmandu Univ Med J. 2004;2:6-12.

15. Oreskovic NM, Sembrano EU. Repeat urine cultures in children who are admitted with urinary tract infections. Pediatr. 2007;119:325-9.

16. Moderres S, Oskoii NN. Bacterial etiologic agents of urinary tract infection in children in the Islamic Republic of Iran.Eastern Mediterranean Health J. 1997;3:290-5.

17. Das RN, Chandrashekhar TS, Joshi HS, Gurung M, Shrestha N, Shivananda PG. Frequency and susceptibility profile of pathogens causing urinary tract infections at a tertiary care hospital in Western Nepal. Singapore Med J. 2006;47:281-5.

18. Al-Ibrahim AA, Girdharilal RD, Jalal MA, Alghamdy AH, Ghazal YK. Urinary tract infection and vesicoureteral reflux in Saudi children. Saudi J Kidney Dis Transplant. 2002;19:24-8.

19. Rajbhandari R, Shrestha J. Bacteriological study of urinary tract infection and its antibiotic sensitivity test: a hospital based study. J Nepal Assoc Med Lab Sci. 2002;4:26-32.

20. Shrestha B, Basnet RB, Shrestha P, Shahi P. Prevalence of urinary tract infection in female patients attending Kathmandu. Model Hospital. J Nepal Assoc Med Lab Sci. 2005;7:10-4.

Cite this article as: Rezia RA, Vijendra R, Gopi A. A clinical study of uropathogens causing urinary tract infection in children and adolescents in a tertiary care hospital. Int J Basic Clin Pharmacol 2020;9:1549-53. 